ARCHIWA - KanCELARIE - ZBIORY

NR 1 (3)/2010

WiESŁAWA KWIATKOWSKA

\title{
TRADYCYJNY MODEL OPRACOWANIA ZASOBU ARCHIWALNEGO I JEGO ZNACZENIE W DOBIE WSPÓŁCZESNEJ
}

\begin{abstract}
(Celem artykułu jest przypomnienie najważniejszych zasad i metod, skła(dających się na tradycyjny model opracowania zasobu archiwalnego. Stanowił on dorobek archiwistów doby międzywojennej, uzupełniony i podsumowany w pierwszych latach powojennych. W swoich ogólnych podstawach teoretycznych, nakreślonej metodzie badawczej i sposobach realizacji poszczególnych etapów prac pozostał on aktualny do dnia dzisiejszego. Następujący w kolejnych latach rozwój metodyki znacznie poszerzył, a także zmodyfikował niektóre ustalenia klasyków polskiej archiwistyki. Nasilające się w ostatnich czasach negatywne zjawisko podważania dotychczasowego dorobku teoretyczno-metodycznego, któremu towarzyszy niejednokrotnie brak rzetelnej wiedzy w tym zakresie, zadecydowały o podjęciu tego zagadnienia $\mathrm{w}$ niniejszym artykule.

Po zakończeniu drugiej wojny światowej archiwa państwowe w Polsce, po oszacowaniu strat, przystąpiły do zakrojonych na szeroką skalę prac zabezpieczających i scaleniowych, następnie rewindykacyjnych. W ich wyniku
\end{abstract}

WiesŁawa Kwiatkowska - Instytut Historii i Archiwistyki Uniwersytetu Mikołaja Kopernikaw Toruniu, e-mail: wk@umk.pl. Zainteresowania badawcze: archiwistyka, w szczególności metodyka archiwalna, kancelaria XIX-XX w. oraz historia Kościoła ewangelickiego. 
zgromadziły ocalałe zasoby archiwalne, w tym popruskie oraz dokumentację przedwojennych oraz okupacyjnych urzędów i instytucji. Z kolei przemiany ustrojowe (reforma rolna, dekret o nacjonalizacji przemysłu) spowodowały napływ do archiwów wielu archiwaliów nowego typu: podworskich, przemysłowych, bankowych, miejskich. Zasób archiwów wzrósł z 25000 metrów bieżących w roku 1947 aż do 90000 w 1953, czyli prawie czterokrotnie w ciągu sześciu lat. Przejęte akta były na ogół nieuporządkowane, pozbawione ewidencji, często wymieszane i rozproszone. Zburzeniu także uległ porządek ocalałych zasobów archiwów przedwojennych (w roku 1947 tylko $25 \%$ zgromadzonych archiwaliów było w pewnym stopniu dostępne dla użytkowników) ${ }^{1}$.

Najważniejszym celem dla archiwów, wytyczonym przez kolejnych Naczelnych Dyrektorów Archiwów Państwowych (Rafała Gerbera i Henryka Altmana), stało się opracowanie zgromadzonych akt, i to jak najszybciej, w sposób umożliwiający ich udostępnienie dla badań naukowych oraz bieżących potrzeb państwa i obywateli ${ }^{2}$.

Do systematycznych prac porządkowo-inwentaryzacyjnych archiwiści przystąpili od początku lat pięćdziesiątych XX wieku. Przy realizacji tego niesłychanie trudnego zadania mieli do dyspozycji niemały dorobek polskiej myśli archiwalnej dwudziestolecia międzywojennego ${ }^{3}$. Tworzyły go liczne referaty i artykuły, wygłoszone przede wszystkim na IV Powszechnym Zjeździe Historyków Polskich (poruszające istotne dla opracowania kwestie, jak interpretacja zasady proweniencji czy systematyzacja pomocy archiwalnych autorstwa m.in. A. Bachulskiego, A. Kaletki, K. Konarskiego, S. Kutrzeby, J. Paczkowskiego, J. Siemieńskiego) ${ }^{4}$, posiedzeniach Sekcji Archiwalnej Towarzystwa Miłośników Historii w Warszawie (referaty K. Konarskiego dotyczące terminologii, które zapoczątkowały dyskusję i badania z udziałem

1 J. Jankowska, Państwowy zasób archiwalny i prace nad nim $w$ Polsce Ludowej, Archeion, t. 24, 1955, s. 16-17; por. W. Kwiatkowska, Miejsce opracowania zasobu we wspótczesnej myśli i praktyce archiwalnej, [w:] Toruniskie Konfrontacje Archiwalne, t. 1: Archiwistyka na uniwersytetach, archiwistyka w archiwach, red. W. Chorążyczewski, A. Rosa, Toruń 2009, s. 33-52.

2 R. Gerber, Cele $i$ zadania stużby archiwalnej $w$ Polsce, Archeion, t. 19/20, 1951, s. 6-18; H. Altman, W dziesięciolecie dekretu o archiwach, Archeion, t. 37, 1962, s. 7-17.

3 Szerzej dorobek archiwistyki międzywojennej został omówiony w: B. Ryszewski, O badaniach i dorobku archiwistyki polskiej z lat 1918-1939, Acta Universitatis Nicolai Copernici, Historia 19, 1984, s. 173-202; A. Tomczak, Dotychczasowy dorobek archiwistyki polskiej, [w:] Studia Historico-Archivistica, Torun 2002, s. 193-202.

${ }_{4}$ Pamiętnik IV Powszechnego Zjazdu Historyków Polskich w Poznaniu 6-8 grudnia 1925, t. 1: Referaty, Lwów 1925, sekcja VIB; t. 2: Protokóty, Lwów 1927, sekcja VIB. 
m.in. R. Przelaskowskiego, J. Siemieńskiego, oraz projekt przewodnika po archiwach doby porozbiorowej) $)^{5}$. Mniejszą rolę odegrały kolejne zjazdy historyków (m.in. referat A. Bachulskiego i A. Stebelskiego dotyczący zabezpieczania i inwentaryzacji archiwów nowoczesnych na $V$ Zjeździe ${ }^{6}$ ). Do powstania wielu prac o charakterze metodycznym przyczyniły się kursy archiwalne (seria „Wydawnictwa Kursów Archiwalnych”), a przede wszystkim działalność wydawnicza władz archiwalnych: seria „Wydawnictwo Archiwów Państwowych” i czasopismo naukowe poświęcone sprawom archiwalnym „Archeion”. Wśród tych publikacji decydujące znaczenie dla rozwoju metodyki archiwalnej mają dwa opracowania syntetyczne: Kazimierza Konarskiego Nowożytna archiwistyka polska i jej zadania (poprzedzona artykułem $Z$ zagadnień nowożytnej archiwistyki polskiej ${ }^{7}$ ) i Ryszarda Przelaskowskiego Program prac wewnętrznych $w$ archiwach nowożytnych ${ }^{8}$.

Dorobek ten został uzupełniony w okresie powojennym, przede wszystkim w pełniącym przez długie lata funkcję zastępczego podręcznika archiwistyki tomie 19-20 „Archeionu”, a w zakresie kwestii terminologicznych w słowniku archiwalnym ${ }^{10}$. Szczególne znaczenie miały zaktualizowane rozważania ogólne Konarskiego oraz artykuły dotyczące ogólnych metod porządkowania i brakowania akt, metod opracowania dokumentacji określonych typów bądź epok czy wreszcie pomocy archiwalnych ${ }^{11}$. Nakreślone przez czołowych polskich archiwistów pokolenia międzywojennego zasady i metody opracowania były podsumowaniem ich własnych doświadczeń, uzupełnionych (zwłaszcza Adam Stebelski) dobrą znajomością światowej literatury archiwalnej. Złożyły się one na ogólny model opracowania archiwalnego, który okazał się trwałym fundamentem do dnia dzisiejszego.

5 Sekcja Archiwalna Towarzystwa Mitośników Historii w Warszawie 1919-1926-1936, Archeion, t. 14, 1936, s. 171-174.

6 Pamiętnik V Powszechnego Zjazdu Historyków Polskich w Warszawie, Lwów 1930.

7 K. Konarski, Z zagadnień nowożytnej archiwistyki polskiej, Archeion, t. 1, 1927, s. 106-124; tenże, Nowożytna archiwistyka polska i jej zadania, Warszawa 1929.

8 R. Przelaskowski, Program prac wewnętrznych w archiwach nowożytnych, Warszawa 1935.

9 Archeion, t. 19/20, 1951.

10 Polski stownik archiwalny, oprac. A. Bachulski, K. Konarski, A. Wolff, Warszawa 1952.

11 K. Konarski, Podstawowe zasady archiwistyki, Archeion, t. 19/20, 1951, s. 19-104; A. Stebelski, Porządkowanie akt, tamże, s. 105-138; ponadto por.: K. Kaczmarczyk, J. Karwasińska, A. Wolff, Opracowanie dokumentów pergaminowych w archiwum, tamże, s. 139-177; P. Bańkowski, Porządkowanie archiwaliów prywatnych, tamże, s. 194-216; A. Bachulski, Brakowanie akt, tamże, s. 240-253. 


\section{DOROBEK ARCHIWISTYKI MIĘDZYWOJENNEJ W ZAKRESIE OPRACOWANIA}

W świetle dorobku polskiej archiwistyki międzywojennej podstawową zasadą, którą należało respektować przy opracowaniu akt, była zasada proweniencji, dla której przyjął się wówczas inny także termin - „zasada przynależności kancelaryjnej"12. Nawiązywała ona do klasycznej definicji, przyjętej przez Kongres Bibliotekarzy i Archiwistów w Brukseli z 1910 roku, i brzmiała: „Każdy dokument winien w archiwum trafić do tego zespołu, a w zespole na to miejsce, jakie zajmował wówczas, kiedy zespół ten był registraturą żywego jeszcze urzędu"13. Interpretacja taka dominowała wśród archiwistów, pomimo że rodziła $\mathrm{w}$ polskich warunkach liczne trudności w pojmowaniu zespołu archiwalnego i jego porządku wewnętrznego. Miała ona decydujący wpływ na powszechne w okresie międzywojennym registraturalne (kancelaryjne) rozumienie zespołu archiwalnego, łączące jego formę z registraturą, a nie z ustrojowo odrębnym urzędem ${ }^{14}$. Według podręcznikowej definicji K. Konarskiego zespół archiwalny to „Jednostka archiwalna, stanowiąca organiczną całość i składająca się z całokształtu registratury danego urzędu"15. Rozwinął ją R. Przelaskowski, według którego „zespołem nazywamy więc jednostkę archiwalną (grupę akt przechowywaną w archiwum), stanowiącą organiczną całość i będącą zarchiwalizowaną w całości lub części registraturą jakiegoś urzędu"16.

12 J. Paczkowski, Zasada archiwalna proweniencji, [w:] Pamiętnik IV Powszechnego Zjazdu, t. 1, s. 130-135, zakwestionował on na IV Powszechnym Zjeździe Historyków termin „zasada proweniencji” i zaproponował nowy - „zasada przynależności kancelaryjnej”. Został on zaakceptowany przez środowisko archiwalne i znalazł swoje odbicie m.in. w podręcznikach K. Konarskiego i R. Przelaskowskiego.

13 K. Konarski, Nowożytna archiwistyka polska, s. 28-29; R. Przelaskowski, dz. cyt., s. 17.

14 B. Ryszewski, O badaniach i dorobku, s. 197-198. Konsekwencją takiej interpretacji było stanowisko autorów „Objaśnień do ankiety archiwalnej” z 1934 r., zgodnie z którym uznano, że jeśli dany urząd posiadał kilka odrębnych registratur, to tworzyły one oddzielne zespoły.

15 K. Konarski, $Z$ zagadnień nowożytnej, s. 109; tenże, Nowożytna archiwistyka polska, s. 146. Zamieszczony tam Stownik ważniejszych terminów archiwalnych, obok pojęcia zespołu wprowadził pojęcie: „Zasób archiwalny (Collection). Zbiór archiwaliów powstałych najczęściej drogą kolekcji, nie powiązanych ze sobą kancelaryjnie, a łączonych w jedną całość bądź swym charakterem [...], bądź treścią [...], bądź po prostu sposobem powstania”.

16 R. Przelaskowski, dz. cyt., s. 19. 
Registraturalne podejście do zespołu pozwalało na rozwiązanie wielu trudności związanych $\mathrm{z}$ występującym $\mathrm{w}$ archiwach na bardzo dużą skalę problemem sukcesji akt. Postępowanie z aktami odziedziczonymi budziło w okresie międzywojennym wiele kontrowersji. W polskiej myśli archiwalnej można było spotkać różne stanowiska, od postulujących rygorystyczne rekonstruowanie registratur pierwotnych jako zespołów archiwalnych, zgodnie z kongresową formułą zasady proweniencji (A. Kaletka, A. Bachulski i większość uczestników sekcji archiwalnej IV Powszechnego Zjazdu Historyków), po dopuszczające różne możliwości rekonstrukcji registratur, ale uznające za najlepszy stan registratury w momencie jej archiwizacji (początkowo odosobnione stanowisko J. Siemieńskiego, z czasem poparte przez T. Manteuffla, autorów „Objaśnień do ankiety archiwalnej” z 1934 roku, R. Przelaskowskie$\mathrm{go}^{17}$. Ten ostatni stworzył nową zasadę dziedziczenia na określenie postępowania, polegającego na tworzeniu zespołu z registratury ostatniego twórcy wraz z aktami odziedziczonymi, jeśli sukcesor przejął je w sposób uzasadniony i nowa registratura tworzy z nimi całość ${ }^{18}$. Pomiędzy tymi stanowiskami były głosy pośrednie, wśród nich $\mathrm{K}$. Konarskiego, który uważał, że należy dążyć do rekonstrukcji registratur pierwotnych, ale można z niej zrezygnować, gdy mamy registratury zrośnięte i ich podział spowodowałby dezorganizację lub byłby niemożliwy do przeprowadzenia. W konsekwencji aprobował on tworzenie zespołów złożonych i proponował sposoby postępowania z nimi, ilustrując to konkretnymi przykładami ${ }^{19}$.

W swoich zasadniczych elementach, jako konsekwencja zasady proweniencji, została opisana podstawowa dla opracowania metoda rekonstrukcji zespołu archiwalnego. Składała się ona z ciągu badań i czynności technicznych, prowadzących od wyodrębnienia zespołu archiwalnego do jego uporządkowania i opracowania pomocy archiwalnych ${ }^{20}$. Jej zarys przedstawił w latach dwudziestych Józef Paczkowski, który opracowanie sprowadził do następujących zadań: rozpoznanie przynależności kancelaryjnej akt, następnie zapoznanie się z ustrojem twórcy i wreszcie określenie, na podstawie analizy kancelaryjnej, pierwotnego porządku archiwaliów i jego rekon-

17 B. Ryszewski, O badaniach i dorobku, s. 181-183, 197-199; tenże, Problem zespotowości $w$ archiwistyce, [w:] Komputeryzacja archiwów, t. 3: Problemy zespotowości w archiwistyce i praktyce archiwów, red. H. Robótka, Toruń 1997.

${ }_{18}$ R. Przelaskowski, dz. cyt., s. 22-26; por. B. Ryszewski, O badaniach i dorobku, s. 198.

${ }^{19}$ K. Konarski, $Z$ zagadnień nowożytnej, s. 112-114; tenże, Nowożytna archiwistyka polska, s. 66-69; por. B. Ryszewski, O badaniach i dorobku, s. 197.

20 B. Ryszewski, Problemy i metody badawcze archiwistyki, Toruń 1989, s. 55-56. 
strukcja ${ }^{21}$. Ustalenia te zostały następnie rozwinięte przede wszystkim przez K. Konarskiego i R. Przelaskowskiego. Obiektem opracowania był dla nich, zgodnie z zasadą proweniencji, zespół archiwalny, a celem - odtworzenie pierwotnego porządku archiwaliów, aczkolwiek odmiennie interpretowali to zagadnienie.

Kazimierz Konarski dzielił prace nad zespołem na dwa podstawowe etapy: klasyfikacja (porządkowanie) i sporządzanie inwentarza, a w dalszej kolejności innych pomocy archiwalnych. Uznając za punkt wyjścia kongresową formułę zasady proweniencji, a za cel nadrzędny prac porządkowych - odtworzenie pierwotnej organizacji zespołu archiwalnego ${ }^{22}$, jednocześnie dopuszczał, w uzasadnionych wypadkach, prawo archiwisty do poprawy błędów w układach kancelaryjnych i dawnych archiwalnych, a nawet do rezygnacji z rekonstrukcji registratur pierwotnych, jeśli prowadzą one do dezorganizacji registratur nowych, uzupełnionych aktami sukcesyjnymi ${ }^{23}$. Zalecał więc postawę kompromisową: „Nie można zatem mówić o konieczności rekonstrukcji dawnego układu, ale tylko o dążności w tym kierunku, która bezwzględnie zatrzymać się winna tam, gdzie albo przeszkody będą zbyt wielkie, albo nakład pracy nie znajdzie odpowiedniego równoważnika w rezultatach owego wysiłku"24.

W klasyfikacji akt wyróżniał dwie podstawowe sytuacje:

1. Porządkowanie zdezorganizowanego zbioru archiwalnego, w tym a) pozbawionego pomocy kancelaryjno-archiwalnych lub b) posiadającego je;

2. Przebudowa zespołu wadliwie zorganizowanego.

W pierwszym przypadku (1a) zakres prac porządkowych obejmował: klasyfikację wstępną, czyli rozpoznanie przynależności zespołowej akt na podstawie znaków rozpoznawczych występujących na archiwaliach i ewentualnie podział ich na zespoły; jej uzupełnienie stanowiły (prowadzone wcześniej i równolegle) studia teoretyczne nad ustrojem urzędu oraz składem, dziejami i ustrojem zespołu; podział wydzielonego zespołu na jego części składowe, mające różne znaczenie, w tym stanowiące „niejako kręgosłup” registratury

21 Tenże, O badaniach i dorobku, s. 180-181.

22 K. Konarski, Nowożytna archiwistyka polska, s. 55-66, opisując różne znane $\mathrm{w}$ archiwach sposoby układu/klasyfikacji akt: alfabetyczny, chronologiczny, rzeczowy, organiczny, za właściwy uznawał tylko ten ostatni, pozostałe mogły być zastosowane, gdy były zgodne z porządkiem organicznym; tamże, s. 60: „Układ organiczny nie narzuca z zewnątrz podziału, ale przyjmuje i podtrzymuje naturalny podział, wynikający z charakterystyki i organizacji zespołu, podział zatem na części, odpowiadające poszczególnym gałęziom urzędu, z którego dany zespół pochodzi”.

23 Tamże, s. 66-69.

24 Tamże, s. 66-67. 
i drugorzędne; dalej klasyfikacja poszczególnych woluminów i nadanie układu całości zespołu ${ }^{25}$.

Gdy archiwista dysponował pomocami (1b) odpowiadającymi prawidłowemu układowi akt, jego praca polegała w zasadzie na rekonstrukcji/odtworzeniu tego porządku, natomiast w przypadku błędów podejmował czynności należące do drugiej sytuacji (2). Przywracanie zespołowi jego pierwotnej organizacji należało do zabiegów bardzo trudnych i wymagających dużego nakładu pracy. Według K. Konarskiego najlepszym sposobem postępowania w tej sytuacji było sporządzenie najpierw inwentarza kartkowego i nadanie prawidłowego układu za pomocą kart, a dopiero potem klasyfikacja samych akt. W niektórych przypadkach praca klasyfikacyjna obejmowała także akta luźne, w tym odtwarzanie rozbitych i tworzenie nowych woluminów. Przeprowadzone zgodnie z zasadą proweniencji porządkowanie zespołu archiwalnego pozwalało na jego dalszą rekonstrukcję, w miarę dopływu kolejnych archiwaliów ${ }^{26}$.

Kolejna czynność, po klasyfikacji akt, polegała na sporządzeniu inwentarza, określonego przez K. Konarskiego jako „spis akt zespołu archiwalnego, zawierający najważniejsze elementy rozpoznawcze poszczególnych woluminów, jak sygnatura, tytuł, data, liczba stron" 27 . Wyróżnił on inwentarze zwykłe, czyli spisy odpowiadające układowi akt na półkach, i systematyczne, mające utrwalony układ pierwotny akt; następnie - realne i idealne; a pod względem formy - książkowe i kartkowe.

Każdy inwentarz powinien składać się ze wstępu i właściwego inwentarza. Wstęp ma obejmować trzy części:

1. Dzieje urzędu: ustrojowe, a nie polityczne, przedstawione w sposób możliwie lakoniczny;

2. Dzieje zespołu: losy akt, prace rekonstrukcyjne, charakterystyka zawartości zespołu, miejsce przechowywania w archiwum, stan jego zachowania, opracowane bardzo szczegółowo;

3. Dzieje inwentarza: opis dawnych inwentarzy i ostatnich prac inwentaryzacyjnych.

Właściwy inwentarz w formie ostatecznej miał postać księgi z następującymi rubrykami:

1. Sygnatura woluminu nowa i stara-ustalała miejsce jednostki w inwentarzu oraz ułatwiała odszukanie jej w magazynie, zalecana numeracja kolejna;

\footnotetext{
25 Tamże, s. 72-75.

26 Tamże, s. 75-80.

27 Tamże, s. 82.
} 
2. Data - daty krańcowe, z reguły podane na okładce, rozwiązania pochodzące od archiwisty należało umieszczać w klamrach [ ], przy wątpliwościach dodany znak zapytania;

3. Tytuł - ścisły i możliwie pełny, wskazana modernizacja pisowni, prawo archiwisty do uzupełniania tytułów zbyt lakonicznych, skracania zbyt obszernych, poprawy błędów, a w przypadku braku oryginalnych - do nadawania własnych, uzupełnienia i komentarze archiwisty umieszczane w klamrach, tytuły obcojęzyczne pisane alfabetem łacińskim, zachowane tytuły oryginalne, tytuły pisane cyrylicą - dozwolone trzy metody: tłumaczenie na język polski, zachowanie języka rosyjskiego, transkrypcja tekstu rosyjskiego - uznana za najbardziej poprawny sposób postępowania;

4. Liczba kart, względnie stron - karty niezapisane nie podlegały numeracji, liczba powinna być podana w końcowej formule;

5. Uwagi - informacje dodatkowe, przestrzega przed jej nadużywaniem.

Według K. Konarskiego inwentarz powinien orientować użytkownika w jednostkach tworzących zespół, ale nie stanowić streszczenia ich zawartości (to rola regestów). We wszystkich etapach opracowania zespołu zalecał on wykorzystywanie identycznego pod względem zawartości inwentarza kartkowego: przy pracach porządkowych, w czasie i po sporządzeniu inwentarza książkowego, w tym do opracowania katalogów tematycznych. Zaproponowana forma inwentarza miała być dostosowywana do określonych rodzajów zespołów, a zwłaszcza dokumentacji (np. kartograficzna, tłoki pieczętne) ${ }^{28}$.

Uzupełnieniem obowiązkowego zakresu prac nad zespołem było sporządzanie dodatkowych pomocy archiwalnych, w tym stanowiących pochodną inwentarzy - katalogów opracowywanych pod kątem wybranych zagadnień oraz skorowidzów (repertorium, klucz, wskaźnik, indeks) ${ }^{29}$. Orientację w całym zasobie archiwum miał dawać inwentarz inwentarzy o organicznej (ustrojowej) budowie, w którym każdy zespół byłby opisany według jednolitego formularza: 1. Numer kolejny, 2. Notatka wskazująca miejsce przechowywania zespołu w magazynie, 3. Data rozpoczęcia i zakończenia zespołu, 4. Nazwa urzędowa zespołu, 5. Liczba woluminów zespołu, 6. Uwagi ${ }^{30}$.

Całościowy obraz wzorowego i nowoczesnego opracowania akt w archiwach przedstawił w latach trzydziestych Ryszard Przelaskowski, wprowa-

\footnotetext{
28 Tamże, s. 81-107.
}

29 Tamże, s. 105-106, 108-125; B. Ryszewski, O badaniach i dorobku, s. 191-192. K. Konarski nawiązał do ustaleń J. Siemieńskiego, Roztrząsania terminologiczne, Archeion, t. 3, 1928, s. 12-22; t. 4, 1928, s. 45-53; t. 5, 1929, s. 59-64, który dokonał systematyzacji pomocy archiwalnych: spis, wykaz, inwentarz i jego rodzaje, katalog, skorowidze.

30 K. Konarski, Nowożytna archiwistyka polska, s. 101-102. 
dzając w wielu kwestiach nowatorskie i odkrywcze niejednokrotnie treści. Dotyczyły one przede wszystkim zasady proweniencji z odmiennościami, wynikającymi ze sformułowanej przez niego zasady dziedziczenia i wynikającego z niej pojęcia zespołów dziedziczących. Prace nad zespołem obejmowały dwa zasadnicze etapy: rekonstrukcję (nazwaną przez K. Konarskiego klasyfikacją) i inwentaryzację systematyczną, poprzedzone studium historycznym obejmującym zapoznanie się: „z historią, organizacją i kompetencjami urzędu, którego akta ma się porządkować, z ustrojem jego kancelarii, systemem urzędowania, wreszcie nawet czasami ze składem osobowym" 31 .

Rekonstrukcja archiwalna składała się z dwóch czynności: a) kwalifikowania akt do zespołu, b) ustalenia miejsca tych akt w obrębie zespołu. Zgodnie z zasadą proweniencji i zasadą dziedziczenia miała więc doprowadzić „do odtworzenia całokształtu registratury, i to tak, jak ona była ułożona”" ${ }^{2}$, przy czym R. Przelaskowski przyjmował za podstawę rekonstrukcji ostatni etap życia registratury, czyli moment archiwizacji, dopuszczając jednocześnie odstępstwa od tej zasady tylko wówczas, gdy akta odziedziczone zachowały autonomię (nie były kontynuowane) i zespół pierwotny istnieje. W skrajnych przypadkach uznawał za możliwe nadawanie aktom układów własnych aposteriorycznych.

Rozróżniał rekonstrukcje realne i idealne. Te pierwsze obejmowały kilka sytuacji związanych z wyodrębnianiem zespołów:

1. Porządkowanie akt zespołu, który nie wchłonął żadnej obcej registratury ani nie podlegał wielkim komplikacjom - tworzenie zespołów prostych;

2. Porządkowanie zespołów obejmujących akta odziedziczone - tworzenie zespołów dziedziczących, zawierających nie tylko akta własne, ale i obce, odziedziczone $\mathrm{z}$ innych registratur, zgodnie z zasadą dziedziczenia, aczkolwiek z możliwymi odstępstwami;

3. Porządkowanie akt powiązanych w sposób uniemożliwiający ich podział na odrębne zespoły - tworzenie w wyjątkowych sytuacjach zespołów złożonych ${ }^{33}$.

Rekonstrukcja idealna, dokonywana w uzasadnionych wypadkach, polegała na sporządzeniu inwentarzy idealnych, w których scalano brakujące/rozproszone części zespołu ${ }^{34}$.

31 R. Przelaskowski, dz. cyt., s. 17, 27-28, ze swoich rozważań wyłączył on dokumentację nieaktową i zbiory, które wymagały zastosowania odmiennych metod porządkowania.

32 Tamże, s. 26.

33 Tamże, s. 22-26.

34 Znaczenie to jest w zasadzie zgodne z przyjętym w słowniku archiwalnym z $1952 \mathrm{r}$. dla terminu „rekonstrukcja archiwalna”: „rekonstrukcja archiwalna - 1. odtwarzanie [...] 


\section{WiEsŁaWA KwiatKowsKa}

Rezultatem kolejnej czynności, czyli inwentaryzacji, było sporządzenie inwentarza systematycznego, odzwierciedlającego przeprowadzoną rekonstrukcję. Ryszard Przelaskowski wyróżniał ponadto inwentarze topograficzne, które, w przypadku zgodności układu akt na półkach z przeprowadzoną rekonstrukcją, były jednocześnie inwentarzami systematycznymi, a z uwagi na stosunek do rzeczywistości - realne i idealne. Inwentarz systematyczny jako pomoc informacyjna musiał zawierać informacje o zawartości poszczególnych jednostek. Wykaz akt należało poprzedzić referatem o zespole, który miał omawiać:

1. Dzieje urzędu - jego kompetencje, skład i organizację;

2. Dzieje kancelarii, registratury i zespołu z uwzględnieniem przeprowadzonych prac archiwalnych;

3. Charakterystykę dzisiejszego stanu zespołu z omówieniem istniejących pomocy archiwalnych oraz wskazówkami dotyczącymi sposobu prowadzenia poszukiwań.

Ryszard Przelaskowski kładł nacisk na staranne, a jednocześnie lakoniczne opracowanie referatów, obejmujących także dzieje tych twórców, których registratury nie utworzyły samodzielnych zespołów. Nie zajął się natomiast samym inwentarzem, jego zawartością ani sposobem wypełniania poszczególnych treści ${ }^{35}$.

Zrekonstruowanie i opisanie zespołów w inwentarzach systematycznych i topograficznych powinno stanowić punkt wyjścia do opracowania dalszych pomocy archiwalnych, ułatwiających poszukiwania w zasobach archiwalnych. Według R. Przelaskowskiego rozwinięcie podstawowej formy inwentarza mogłyby stanowić inwentarze analityczne, uzupełnione o analizę zawartości poszczególnych woluminów i rotulusy, czyli spisy akt zawartych w danej jednostce, następnie katalogi, czyli inwentarze oparte na klasyfikacji logicznej, rzeczowej, oraz skorowidze. Kolejne pomoce, tworzące przemyślany system informacji archiwalnej, sporządzane dla całych zasobów archiwalnych (ogólne pomoce archiwalne), to: kartoteka zespołów (karty zespołów/registratur istniejących, wchłoniętych, zaginionych lub wywiezionych, opracowane na podstawie ankiety, ułożone według kryteriów historyczno-ustrojowych), inwentarz generalny archiwum (składający się z dwóch części: 1 . referat o historii archiwum, 2 . spis wszystkich aktualnych pomocy archiwalnych, usystematyzowanych według zespołów, zgodnie z kartoteką), plan topograficznego

pierwotnego układu i zawartości jednostki lub zespołu archiwalnego, rozproszonego, zachowanego częściowo lub nieistniejącego dla ewentualnego scalenia lub opracowania inwentarza idealnego", zob. Polski stownik archiwalny, Warszawa 1952, s. 23.

35 R. Przelaskowski, dz. cyt., s. 28-29. 
rozmieszczenia archiwaliów (jako lepsze rozwiązanie niż odpowiednie adnotacje w inwentarzu generalnym czy kartotece ${ }^{36}$.

Uzupełnienie tych całościowych wskazówek teoretyczno-metodycznych w zakresie sporządzania dodatkowych pomocy archiwalnych stanowiły koncepcje przewodników historyczno-ustrojowych. Powstał wówczas przewodnik Józefa Siemieńskiego po archiwach dawnej Rzeczypospolitej oraz projekt przewodnika po polskich archiwach państwowych doby porozbiorowej. Podstawą opracowania tego ostatniego miała być ankieta, na którą odpowiedzi utworzyłyby kartotekę, pełniącą także funkcję stale aktualizowanej kartoteki generalnej archiwów państwowych ${ }^{37}$.

\section{ROZWóJ MODELU OPRACOWANIA ZASOBU ARCHIWALNEGO W OKRESIE POWOJENNYM}

Okres powojenny wzbogacił dorobek wcześniejszy o kolejne prace, które uzupełniły i rozwinęły w sposób bardziej szczegółowy dotychczasowe ustalenia teoretyczne i metodyczne.

W świetle ukształtowanego ostatecznie wzorca podstawową zasadą, którą należało respektować przy opracowaniu, pozostała zasada proweniencji, nazywana zamiennie zasadą przynależności zespołowej lub zasadą przynależności kancelaryjnej. Zgodnie z brzmieniem przyjętym w słowniku archiwalnym z 1952 roku oznaczała ona: 1. poszanowanie związku zachodzącego pomiędzy aktami a kancelarią, która ten zespół wytworzyła, oraz 2. między aktami zespołu między sobą (niepodzielność) ${ }^{38}$. W konsekwencji obiektem opracowania był zespół archiwalny, a „,o w zespole powstało, to w tym samym składzie i układzie zachowane i przechowywane być na zawsze powinno" ${ }^{39}$.

Zostały sformułowane podstawowe pojęcia archiwalne, w tym pojęcie zespołu archiwalnego, wyszczególnione rodzaje zespołów (otwarty i zamknięty, prosty i złożony, kompletny i szczątkowy), zarysowana struktura zespołu (serie) i zasobu archiwalnego (grupa zespołów, zespoły, zbiory, kolekcje). Wykładnia terminologiczna przyjęta w Polskim stowniku archiwalnym nawiązy-

36 Tamże, s. 30-39, poza tymi zasadniczymi pomocami ogólnymi zalecał prowadzenie księgi nabytków i ubytków, księgi rewizji zasadniczej i skontrów, teki referatów o zespołach i registraturach, katalogu akt dotyczących zagadnień archiwalno-ustrojowych, bibliografii zagadnień archiwalno-ustrojowych.

37 B. Ryszewski, O badaniach i dorobku, s. 192-196, omawia prace nad przewodnikami i ich budowę.

38 Polski stownik archiwalny, Warszawa 1952, s. 21-22.

39 K. Konarski, Podstawowe zasady archiwistyki, s. 47. 
wała wyraźnie do dorobku badań okresu międzywojennego. Zgodnie z nią zespół archiwalny stanowił „wytwór kancelarii (w najogólniejszym tego słowa znaczeniu) - organiczna całość, na którą składają się zarchiwalizowane akta powstałe w wyniku działalności urzędu, instytucji lub osoby" ${ }^{\prime 20}$.

Rozwinięto metodę rekonstrukcji zespołu archiwalnego. Ustalono szczegółowy zakres i sposób wykonania czynności składających się na zasadnicze etapy opracowania: porządkowanie ${ }^{41} \mathrm{i}$ inwentaryzację, poprzedzone rekonstrukcją zespołu (wyodrębnianie). Ich uzupełnienie stanowiły studia nad twórcą i samym zespołem, dla których aktualne pozostały wcześniejsze propozycje K. Konarskiego i R. Przelaskowskiego.

Problemem wyodrębniania zespołów i ustalaniem ich granic zajął się całościowo Kazimierz Konarski. Przedstawił on różne czynniki, mające wpływ na rekonstrukcję zespołów archiwalnych, w tym przede wszystkim związane z dziedziczeniem akt. W przypadku sukcesji biernej uznawał, że akta należy zwrócić zespołowi macierzystemu, natomiast akta kontynuowane w zasadzie pozostawiać u sukcesora, z pełną możliwością dokonywania uzasadnionych odstępstw. Reprezentował pragmatyczne podejście i przyjęte sposoby postępowania przy rekonstrukcji zespołów uzależniał od konkretnej sytuacji. Do czynników, które archiwista powinien brać pod uwagę, zaliczał: hierarchię zespołu, wiek, rozmiary dokonanego błędu, istniejące pomoce, charakter akt $\mathrm{t}^{42}$.

Przez porządkowanie rozumiano „sumę czynności, które ustalają kancelaryjny związek między aktami oraz nadają im taki układ, jaki posiadały one w kancelarii dla nich właściwej”ł3. Ustalony przez Adama Stebelskiego zakres prac porządkowych obejmował następujące obowiązkowe stadia:

1. Rozpoznanie przynależności akt do zespołu,

2. Segregacja akt wedle zespołów, serii itd.,

3. Systematyzacja akt w zespole,

4. Ułożenie akt w zespole,

5. Znakowanie akt według porządku właściwego dla zespołu; oraz czynności dodatkowe:

6. Brakowanie akt zbędnych,

7. Scalanie akt jednej kancelarii ${ }^{44}$.

40 Polski stownik archiwalny, Warszawa 1952, s. 30; por. K. Konarski, Podstawowe zasady archiwistyki, s. 70.

41 Według K. Konarskiego, Podstawowe zasady archiwistyki, s. 86, dalszym po rekonstrukcji etapem prac archiwalnych jest klasyfikacja i porządkowanie, a następnie inwentaryzacja.

42 Tamże, s. 48-69.

43 A. Stebelski, dz. cyt., s. 107.

44 Tamże, s. 109, 135. 
Szczególne znaczenie miała pierwsza czynność, którą należało przeprowadzić na podstawie cech zewnętrznych i wewnętrznych. Do pierwszych A. Stebelski zaliczył przede wszystkim: postać zewnętrzną akt, ich nagłówki, znaki kancelaryjne i archiwalne oraz występujące na piśmie: adres, znaki kancelaryjne i noty dorsalne, a także postać kancelaryjną pisma, natomiast do drugich - treść. Efektem przeprowadzonej analizy było określenie kancelaryjnej przynależności akt, a w dalszej konsekwencji ustalenie granic zespołu.

W wyniku kolejnej czynności dokonywano ewentualnie podziału akt na zespoły i następnie $\mathrm{w}$ ich obrębie na serie ${ }^{45}$. Pierwsza sytuacja dotyczyła archiwaliów dwóch lub więcej przemieszanych zespołów, zarówno obcych pochodzeniem i przynależnością kancelaryjną, jak i wyodrębnionych kancelaryjnie części zespołu złożonego, czy wreszcie przemieszanych kancelaryjnie akt zespołu złożonego. W tej ostatniej sytuacji A. Stebelski zalecał indywidualne podejście do każdego przypadku i w zależności od wyników analizy i stopnia powiązania akt kancelarii odziedziczonej z aktami kancelarii dziedziczącej proponował albo dokonywanie podziału na zespoły proste, albo pozostawianie zespołów złożonych. W ramach wyodrębnionego zespołu akta segregowano na serie, wydzielane według różnych kryteriów (formalne - zewnętrzna postać aktu, struktura organizacyjna twórcy, jego zakres działania, charakter prawny akt), mające własny porządek wewnętrzny i wynikającą z niego kolejność poszczególnych jednostek ${ }^{46}$.

Systematyzacja zmierzała do ustalenia miejsca akt w zespole, a więc odtworzenia, o ile to możliwe, kancelaryjnego porządku akt w zespole ${ }^{47}$. Do materiałów pozwalających na przeprowadzenie tej czynności A. Stebelski zaliczał zachowane spisy i plany/wykazy akt, następnie znaki rozpoznawcze akt,

45 W słowniku archiwalnym z 1952 r. wprowadzono dwa terminy na określenie czynności porządkowania, polegającej na podziale akt, w zależności od przyjętych kryteriów: segregacja i klasyfikacja. Segregacja akt - podział akt w toku porządkowania według zewnętrznych kryteriów kancelaryjnych, Polski stownik archiwalny, Warszawa 1952, s. 24-25. W powikłanych wypadkach lub w razie braku kryteriów zewnętrznych stosuje się klasyfikację, czyli podział akt w toku porządkowania według kryteriów wewnętrznych, tamże, s. 14.

46 A. Stebelski, dz. cyt., s. 124: „W zespole prostym każda seria stanowi całość wyodrębniającą się czymś spośród innych jego akt; ma ona też swój własny porządek wewnętrzny i wypływającą stąd kolejność i ciągłość układu akt”.

47 Polski stownik archiwalny, Warszawa 1952, s. 26, systematyzacja akt - czynność porządkowania akt, zmierzająca do odtworzenia kancelaryjnego porządku akt w zespole; por. tamże, s. 27, układ akt - 1. porządek akt w zespole lub zbiorze (kancelaryjny, przypadkowy, alfabetyczny, chronologiczny, numerowy, rzeczowy itd.), 2. sposób rozmieszczenia akt na półce: stojąco, leżąco itd. 
przede wszystkim sygnatury kancelaryjne. Zwracał uwagę na przestrzeganie przy przeprowadzanej analizie ogólnych zasad metodycznych, przy jednoczesnym uwzględnianiu indywidualnych cech danego zespołu i wyjątkowym dopuszczaniu możliwych odstępstw. Zasady te sprowadził do dwóch następujących:

1. o porządku akt w zespole decyduje znak akt nadany im w kancelarii [...] znak akt nadany im w archiwum lub zbiorze wchodzi w rachubę tylko wówczas, gdy brak kancelaryjnego [...]

2. w wypadku, gdy akta posiadają dwa lub więcej znaków, ten z nich jest właściwy [...], który jest chronologicznie późniejszy, tj. ten, który ustala ostatni porządek kancelaryjny akt ${ }^{48}$.

Prawo archiwisty do ingerencji w układy pierwotne Stebelski ograniczył tylko do usunięcia oczywistych błędów, zakazując jednocześnie poprawy całości, nawet gdyby była ona chaotyczna i niekonsekwentna. Operacja taka mogła zostać zastosowana jedynie w odniesieniu do układów nadanych w archiwum czy zbiorze ${ }^{49}$.

W przypadku braku zachowanych pomocy i znaków kancelaryjnych archiwista powinien dążyć do nadania zespołowi porządku maksymalnie zbliżonego do przypuszczalnego układu kancelaryjnego. Przy jego opracowaniu należy oprzeć się na strukturze twórcy, jego zadaniach, a w pewnym zakresie - także dziejach (akta i publikacje). W ostateczności (przy braku jakichkolwiek wskazówek) A. Stebelski dopuszczał układy wydedukowane z treści lub formy akt, ale i w tym wypadku zgodnie z systemem kancelaryjnym właściwym dla danej epoki.

Systematyzacji towarzyszyło z reguły ułożenie akt w porządku przez nią ustalonym. Czynność ta, aczkolwiek prosta i niemal mechaniczna, wymagała przestrzegania pewnych procedur. Według A. Stebelskiego poszczególne części/serie zespołu należało układać oddzielnie, zanim nastąpi ich połączenie w całość. Osobnego traktowania wymagały archiwalia o innej formie kancelaryjnej, które przechowywano oddzielnie, przy jednoczesnym włożeniu karty zastępczej na właściwe miejsce w zespole. Z kolei nadanie aktom znaków archiwalnych towarzyszyło inwentaryzacji i polegało na umieszczeniu na wypustkach i dodatkowo na jednej z wewnętrznych stron oprawy następujących elementów: symbol zespołu, niekiedy także serii, i kolejne liczby. Należało

48 A. Stebelski, dz. cyt., s. 127-128.

49 Tamże, s. 128, wówczas nie była to systematyzacja, ale osobna czynność związana z rekonstrukcją zespołu rozbitego lub rozproszonego i jego scaleniem bądź z opracowaniem zespołu w celu udostępnienia go w należytej postaci. 
zachować ciągłość numeracji w obrębie serii i w zespole prostym, niezawierającym wyodrębniających się serii, w innych sytuacjach było to niewskazane. W przypadku stosowania numeracji tymczasowej znaki te należało umieszczać na osobnych luźnych wkładkach ${ }^{50}$.

Obok tych czynności obowiązkowych zachodziła niekiedy konieczność wykonania dodatkowych prac:

1. Brakowania, polegającego na wydzieleniu z zespołu akt, które utraciły znaczenie praktyczne, i ich zniszczeniu, które w archiwum miało charakter ograniczony lub czasami pełny, gdy nie zostało dokonane u twórcy ${ }^{51}$;

2. Scalania, czyli połączenia akt, stanowiących samoistne grupy czy serie, z zespołem już znajdującym się w archiwum. Porządkowanie dopływów musiało być zgodne z zasadami przyjętymi dla opracowanej już części. Nie należało natomiast wiązać scalania z porządkowaniem akt, będących częściami jakiegoś zespołu złożonego ani tym bardziej zespołu rozproszonego ${ }^{52}$.

Zakres prac porządkowych i ich kolejność zaproponowana przez A. Stebelskiego należało traktować jako pewien model, dostosowywany do konkretnych sytuacji i zespołów. Na jego zmiany (wykonywanie oddzielnie poszczególnych czynności, ich kolejność, pominięcie niektórych) mogły wpływać przede wszystkim następujące czynniki: stan zachowania zespołu; stan przemieszania akt $\mathrm{w}$ zespole; zachowane informacje lub ich brak o porządku kancelaryjnym; warunki, w jakich odbywało się porządkowanie. Mimo że zaproponowana kolejność prac stanowiła logiczny ciąg, to dopuszczalne były odstępstwa, dotyczące nawet wzajemnych relacji między porządkowaniem a inwentaryzacją. W uzasadnionych przypadkach można było rozpocząć opracowanie od inwentaryzacji i za pomocą kart dokonać systematyzacji akt ${ }^{53}$.

50 Tamże, s. 130-134.

51 Tamże, s. 125-126. Brakowanie akt - czynność polegająca na ocenie akt pod kątem widzenia ich wartości naukowej i użytkowej. Brakowanie zmierza do wydzielenia akt niezasługujących na trwałe przechowanie, a zachowania pozostałych bądź w składnicy urzędu (kategoria B), bądź w archiwum (kat. A), Polski stownik archiwalny, Warszawa 1952, s. 7. Wydzielanie akt - ostatnie stadium brakowania akt, polegające na wyłączeniu akt zakwalifikowanych do kategorii B, uznanych zgodnie z przepisami za makulaturę, por. tamże, s. 29.

52 A. Stebelski, dz. cyt., s. 137. Scalenie akt - połączenie jednostki archiwalnej lub zespołu rozbitego między różne zbiory, Polski stownik archiwalny, Warszawa 1952, s. 24.

53 A. Stebelski, dz. cyt., s. 111. W okresie międzywojennym nadanie aktom układu poprzedzała zazwyczaj inwentaryzacja kartkowa. Także po drugiej wojnie światowej ten sposób postępowania miał wielu zwolenników, m.in. należał do nich A. Wolff, i w archiwach szybko powrócono przy opracowywaniu większości zespołów do sprawdzonej 
W dalszej kolejności porządkowanie nie ograniczało się tylko do odtworzenia zespołu archiwalnego jako organicznej całości, ale wymagało także nadania zespołowi należytego porządku w archiwum i w całej sieci archiwalnej, czyli zachowania struktury zasobu archiwalnego, wynikającej z zasady proweniencji ${ }^{4}$.

Inwentaryzacja stanowiła odrębny etap opracowania zespołu i polegała na spisywaniu, opisywaniu według określonego systemu akt w obrębie zespołu 55 . Jej rezultatem był inwentarz zespołu (systematyczny) - czyli „spis akt zespołu (lub jego części), sporządzony według porządku kancelaryjnego akt, zawierający elementy rozpoznawcze i rozstawnicze poszczególnych jednostek archiwalnych" 56 . Inwentarze mogły być realne, idealne, martwe, ponadto z uwagi na stopień szczegółowości opisu - sumaryczne i szczegółowe, a pod względem formy - kartkowe i książkowe ${ }^{57}$.

Prace nad ujednoliceniem formy inwentarza rozpoczęte przed wojną kontynuowano po roku 1945. Projekt karty inwentarzowej opracował Adam Wolff i przedstawił go w marcu 1947 roku na zebraniu Związku Bibliotekarzy i Archiwistów w Warszawie, a następnie w artykule metodycznym ${ }^{58}$. Uznawał inwentaryzację kartkową, poza wyjątkowymi sytuacjami (zespoły bardzo małe lub o utrwalonym układzie kancelaryjnym), za pierwszy etap opracowania. Pomimo że sądził, że ideałem byłaby jedna znormalizowana karta, swój projekt ograniczył do akt, ksiąg i dokumentów, wyłączając dokumentację kartograficzną. Dane służące do opisu jednostek, z uwzględnieniem różnic pomiędzy dokumentami a księgami i aktami, ujął w cztery bloki:

I. Sygnatura, w tym: 1. Symbol archiwum; 2. Zespół, dział, poddział; 3. Numer kolejny;

II. Treść, w tym: 4. Tytuł lub treść (po polsku), dla dokumentów dodatkowo wystawca, język; 5. Data, dla dokumentów dodatkowo miejsce;

metody systematyzacji akt za pomocą kart inwentarzowych (nie wymagały jej zespoły niewielkie, o prostej budowie i utrwalonym układzie kancelaryjnym).

54 Tamże, s. 109: „archiwum gromadzi i przechowuje akta zgodnie ze strukturą i biegiem życia, którego są one rękopiśmiennym przejawem i reliktem”.

55 Polski stownik archiwalny, Warszawa 1952, s. 12, ponadto 1b) w obrębie dwóch lub więcej zespołów dla określonego zagadnienia (por. inwentarz tematyczny, katalog), 2) zespołów: a) w obrębie archiwum (por. inwentarz generalny zespołu, inwentarz rozstawniczy), b) w obrębie sieci archiwalnej (inwentarz zespołów państwowego zasobu archiwalnego).

56 Tamże, s. 12-13.

57 K. Konarski, Podstawowe zasady archiwistyki, s. 88-90; Polski stownik archiwalny, Warszawa 1952, s. 12-13.

58 A. Wolff, Archiwalne karty inwentarzowe, Archeion, t. 17, 1948, s. 152-163. 
III. Opis zewnętrzny, w tym: 6. Wielkość - dla dokumentów wymiar (w mm), dla ksiąg i akt format; 7. Liczba kart lub stron; 8. Oprawa; 9. Stan zachowania; 10. Dodatkowo dla dokumentów materiał, liczba pieczęci;

IV. Różne, w tym: 11. Dawne sygnatury; 12. Druki, reprodukcje; 13. Uwagi, dodatkowo dla ksiąg i akt plany, druki, pieczęcie.

W następnych latach zasady inwentaryzacji zostały dopracowane i wprowadzone do stosowania w archiwach. Według K. Konarskiego inwentarz pełnił dwie, niemal równorzędne funkcje: skarbową (zabezpieczenie całości) i informacyjną, które decydowały o zawartych w nim informacjach ${ }^{59}$. Dla spełniania pierwszej podstawowe znaczenie miały elementy rozpoznawcze formalne (sygnatura, liczba stron/kart), natomiast drugiej - informacja o zawartości akt. Dla akt i ksiąg zawartość należało oddać poprzez tytuł (inwentarz sumaryczny), przy czym podstawową rolę odgrywał tytuł oryginalny, aczkolwiek archiwista miał prawo do jego ewentualnego uzupełniania, skracania lub poprawiania zawartych w nim błędów, tak aby oddawał zawartość $\mathrm{akt}^{60}$. Najdokładniejszy opis treści w postaci regestu zawierały inwentarze dokumentów (inwentarz szczegółowy).

Zgodnie z „Instrukcją wypełniania archiwalnych kart inwentarzowych” karta inwentarzowa dla dokumentacji aktowej (dokumenty, księgi, akta) zawierała dziewięć następujących rubryk:

1. Znak archiwum;

2. Nazwa zespołu;

3. Znak danej jednostki archiwalnej;

4. Tytul, a w inwentarzu dokumentów: wystawca, streszczenie, język;

5. Daty, dla dokumentów rozwiązane (rok, dzień, miesiąc);

6. Opis zewnętrzny, dla dokumentów: wymiary, materiał, liczba pieczęci, stan zachowania, dla ksiąg: liczba stron/kart, format, oprawa, stan zachowania;

7. Stare sygnatury;

8. Informacje bibliograficzne o drukowaniu lub reprodukowaniu jednostki;

59 K. Konarski, Podstawowe zasady archiwistyki, s. 87-88. W dawniejszej szkole archiwalnej (S. Kutrzeba) zarysowała się tendencja do sporządzania dwóch pomocy dla zespołu: inwentarza, służącego do zabezpieczenia zespołu, i katalogu, będącego przewodnikiem po nim.

60 Tamże, s. 92; por. K. Konarski, Nowożytna archiwistyka polska, s. 88-102, znacznie dokładniejsze omówienie zasad inwentaryzacji, zwłaszcza formułowania tytułów; por. A. Wolff, Archiwalne karty inwentarzowe, s. 154-155, uznawał prawo archiwisty do ingerencji w tytuły oryginalne, niepełne lub błędne. 
9. Uwagi - informacje niemieszczące się w poprzednich rubrykach, np. znajdujące się w jednostce plany, druki, pieczęcie ${ }^{61}$.

W sytuacji, gdy układ akt w inwentarzu systematycznym nie odpowiadał ich kolejności na półkach w magazynie, należało uzupełnić go o sygnatury topograficzne. Na podstawie ostatecznie uporządkowanych kart sporządzano inwentarz książkowy. Uznanie formy książkowej za końcową wynikało z jej większej przejrzystości i bezpieczeństwa.

Ostatnim etapem prac inwentaryzacyjnych było opracowanie wstępu do inwentarza według zasad zaproponowanych przez K. Konarskiego ${ }^{62}$. Jego zadaniem było „ułatwienie orientacji w budowie i zawartości grupy akt zwanej zespołem archiwalnym" ${ }^{63}$. Miał on być wykonany w sposób maksymalnie zwięzły i rzeczowy, bez przeradzania się w obszerne studium naukowe. Zawierał on opis twórcy i jego zespołu ujęty w pięć części:

I. Dzieje ustrojowe urzędu - omówione bardzo zwięźle dla twórców opisanych w literaturze, natomiast dokładnie nowe ustalenia ustrojowe; szczególny nacisk na kompetencje urzędu, z rozróżnieniem wprowadzonych w życie i „martwych”;

II. Dzieje zespołu - wnikliwe potraktowanie, z uwzględnieniem wszelkich przeżyć, wstrząsów, przekształceń, podziałów, sukcesji, odstąpień, rewindykacji, ekstradycji, dopływów, zrostów, brakowań itd.;

III. Charakterystyka archiwalna zespołu - najważniejsza i wymagająca najbardziej wyczerpującego omówienia część obejmująca:

1. Tytuł zespołu - jego geneza, ewolucja kolejnych form, uzasadnienie wyboru;

2. Granice chronologiczne - zwrócenie uwagi na rozbieżności granic chronologicznych zespołu z datami krańcowymi urzędu;

3. Granice terytorialne - dokładniejsze omówienie, gdy nie wynikają z nazwy twórcy;

4. Rozmiary zespołu - w jednostkach archiwalnych i metrach bieżących;

5. Procentowy stan zachowania akt $-\mathrm{a}$ ) w stosunku do momentu powstania zespołu, b) w stosunku do stanu posiadania w roku 1939;

6. Struktura archiwalna zespołu: a) typ kancelarii (typ i układ akt), b) komplikacje własne zespołu, bez omawiania procesu rekonstruk-

61 K. Konarski, Podstawowe zasady archiwistyki, s. 91-93.

62 Tenże, Wstęp do inwentarza zespotu archiwalnego. Zasady opracowania, Archeion, t. 21, 1952, s. 192-201, różniły się one od wcześniejszych propozycji, tenże, Nowożytna archiwistyka polska, s. 87-88.

63 Tenże, Podstawowe zasady archiwistyki, s. 193. 
cyjnego (budowa prosta czy złożona, problem sukcesji, odstąpień, podziałów, reorganizacji, gwałtownych likwidacji), c) części składowe zespołu (liczba, wymienienie, stosunek ilościowy, hierarchia, punkt ciężkości zespołu), d) serie ksiąg, dokumentów, akt określonego typu, oddzielnie akta formalne, oddzielnie merytoryczne (typy, charakter, forma, ich częstotliwość i liczebność), e) pomoce archiwalne (dawne i aktualne pomoce, takie jak: inwentarze, skorowidze, rotulusy, ewentualnie szczególne cechy skorowidzów i sposoby posługiwania się nimi), f) zagadnienie sygnatury (typ sygnatur, np. numerus currens, wydziałowe, roczne);

7. Charakterystyka techniczna materiału aktowego - formy techniczne (dokumenty, księgi, poszyty, fascykuły, mapy), ich wzajemny stosunek, wymiary, oprawy odbiegające od przeciętnych;

8. Fizyczny stan zachowania akt - uszkodzenia biologiczne, mechaniczne, przeprowadzone zabiegi konserwatorskie i postulaty na przyszłość;

9. Stan zmikrofilmowania akt - stan aktualny oraz braki w tej dziedzinie;

10. Brakowanie akt zespołu - opis przeprowadzonego brakowania lub postulaty w tej kwestii;

IV. Zawartość zespołu - syntetyczne omówienie treści akt dokonane w sposób problemowy lub wydzielonymi seriami, z położeniem nacisku na informacje nieoczekiwane czy przypadkowe;

V. Analiza metod porządkowania i inwentaryzacji zespołu - przedstawienie przebiegu prac, problemy i trudności występujące na wszystkich etapach, sposoby ich rozwiązania.

Uzupełnienie wstępu stanowiły bibliografia (wydawnictwa źródłowe zawarte w samym zespole, opracowania dotyczące zespołu) oraz notka podająca czas przeprowadzenia prac i dane autora/autorów. Kolejność zaproponowanych części miała charakter ramowy, sposób prezentacji zagadnień mógł być dostosowany do potrzeb danego zespołu.

Oprócz inwentarza ze wstępem, w miarę możliwości i potrzeb były też opracowywane inne pomoce archiwalne. Ich systematyka rozwijała się stopniowo, a najbardziej pełny obraz przedstawił Kazimierz Konarski, a utrwalił słownik archiwalny. Uzupełnieniem inwentarzy były katalogi i skorowidze (indeksy, repertoria, sumariusze) $^{64}$, natomiast jako pomoce ogólne, prowa-

64 Tamże, s. 93-98; Polski stownik archiwalny, Warszawa 1952, s. 12 - inwentarz tematyczny; tamże, s. 14 - katalog; tamże, s. 11-12 - indeks; tamże, s. 23 - repertorium; tamże, s. 25 - skorowidz; tamże, s. 26 - sumariusz. 
dzone dla całego zasobu danego archiwum, Konarski proponował m.in.: inwentarz generalny zespołów (wykaz zespołów), spis inwentarzy, inwentarz rozstawniczy, rejestr przybytków i ubytków ${ }^{65}$. Ich uzupełnieniem, i to bardzo ważnym, były karty zespołów, zawierające opis zespołu z podaniem podstawowych danych liczbowych, chronologicznych i innych ${ }^{66}$.

\section{OCENA TRADYCYJNEGO MODELU OPRACOWANIA}

Ustalone przez czołowych polskich archiwistów pokolenia międzywojennego metody porządkowania i inwentaryzacji złożyły się na ogólny model opracowania zasobu archiwalnego. Jego podbudowę stanowiła zasada proweniencji, a wykonanie prac odbywało się zgodnie z metodami właściwymi dla tej dziedziny archiwalnej (metoda rekonstrukcji zespołu archiwalnego). Istniał ustalony zakres prac porządkowych i znormalizowany opis na poziomie jednostki i całego zespołu. Wzorzec ten opierał się na doświadczeniach archiwistów opracowujących dokumentację do końca XIX wieku, w zasadzie ograniczoną do aktowej. Była ona wytworem na ogół dobrze zorganizowanych i funkcjonujących na podstawie ustalonych przepisów kancelarii instytucji państwowych. W związku z tym nie uwzględniał on specyfiki porządkowania dokumentacji dwudziestowiecznej, zarówno aktowej, jak i przede wszystkim nieaktowej, a także nowych typów zespołów proweniencji niepaństwowej (podworskich, pofabrycznych, miejskich).

Model ten okazał się trwałym fundamentem do dnia dzisiejszego, aczkolwiek jego realizacja wymagała podejmowania działań, które były dostosowywane do konkretnych akt oraz zmieniających się warunków pracy i ich żywotność była odpowiednio krótka. Rozwój metodyki opracowania akt w następnych latach uwzględniał zarówno nowe doświadczenia, wyniesione z porządkowania kolejnych rodzajów archiwaliów, jak i dokonujący się postęp technologiczny. Nastąpiła przede wszystkim ewolucja w rozumieniu zasady proweniencji ${ }^{67} \mathrm{i}$ wynikającego $\mathrm{z}$ niej pojęcia zespołu archiwalnego.

${ }^{65}$ K. Konarski, Podstawowe zasady archiwistyki, s. 99-104; Polski stownik archiwalny, Warszawa 1952, s. 12 - inwentarz generalny zespołów; tamże, s. 12 - inwentarz rozstawniczy; tamże, s. 15 - księga przybytków i ubytków; tamże, s. 24 - skontrum, kontrola akt; tamże, s. 14 - kartoteka.

${ }^{66}$ Polski stownik archiwalny, Warszawa 1952, s. 14 - karta zespołu. Dokładny opis kartoteki zespołów przedstawił R. Przelaskowski, dz. cyt., s. 35-37.

${ }^{67}$ Polski stownik archiwalny, red. W. Maciejewska, Warszawa 1974, s. 89 - zasada proweniencji patrz zasada przynależności zespołowej; tamże, s. 90 - zasada przynależności zespołowej - zasada poszanowania związku materiałów archiwalnych wchodzących 
Pozostała ona podstawą porządku archiwalnego jako zasada przynależności zespołowej, a zespół archiwalny, czyli „organicznie powiązane ze sobą zarchiwalizowane materiały archiwalne wytworzone i zgromadzone w wyniku działalności urzędu (instytucji) lub osoby fizycznej”, podstawową jednostką zasobu i obiektem opracowania ${ }^{68}$. Natomiast, zachowując pierwszeństwo dla układów pierwotnych, uznano za w pełni dopuszczalne stosowanie i innych metod porządkowania akt. Określono zakres prac składających się na ogólny model opracowania, ustalony przez Adama Stebelskiego. Rozwinęła się metodyka szczegółowa, dostosowująca go do specyfiki porządkowania określonych typów zespołów i akt. Zostały ustalone odrębne normy inwentarzy dla poszczególnych rodzajów dokumentacji i dopracowane szczegółowo zasady ich sporządzania. Nastąpił dalszy rozwój innych pomocy archiwalnych, w tym zwłaszcza przewodników ${ }^{69}$.

Dotychczasowe zasady i metody opracowania zachowały aktualność także w dobie komputeryzacji archiwów. Wpływ nowoczesnych technologii na studia wstępne i czynności porządkowe polega jedynie na ich ułatwieniu i uproszczeniu, zwłaszcza w zakresie wyszukiwania informacji i systematyzacji akt. Programy komputerowe nie zastępują natomiast archiwisty ani w wyborze metody porządkowania, ani w opracowaniu układu akt, wykonują jedynie czynności polegające na mechanicznym usystematyzowaniu według kryteriów podanych przez człowieka. Ich wykorzystanie w procesie opracowania polega przede wszystkim na tworzeniu inwentarzy, kart zespołów i innych pomocy archiwalnych. Przystosowanie tradycyjnych pomocy do wymagań programów komputerowych wymagało dalszego uporządkowania i ujednolicenia zawartego w nich opisu, czyli dokonania standaryzacji, pozostającej w zgodzie z dotychczasową teorią i metodyką archiwalną ${ }^{70}$.

w skład zespołu archiwalnego z jego twórcą, decydująca zarazem o niepodzielności zespołu, oddzielona od zasady przynależności kancelaryjnej; tamże, s. 89 - zasada przynależności kancelaryjnej - zasada zachowania w obrębie zespołu kolejności dokumentów (aktów) nadanej im w kancelarii (registraturze) twórcy zespołu.

${ }^{68}$ Tamże, s. 91; trochę inne ujęcie w: H. Robótka, B. Ryszewski, A. Tomczak, $A r-$ chiwistyka, Warszawa 1989, s. 15: „zarchiwizowana całość materiałów archiwalnych wytworzonych i zgromadzonych przez ustrojowo odrębnego twórcę - urząd, przedsiębiorstwo lub inną instytucję albo osobę fizyczną".

69 Całościowy obraz stanu metodyki opracowania można znaleźć przede wszystkim w pracach syntetycznych, zwłaszcza podręcznikach: Cz. Biernat, Problemy archiwistyki wspótczesnej, Warszawa 1977; H. Robótka, B. Ryszewski, A. Tomczak, dz. cyt.; Metodyka pracy archiwalnej, red. S. Nawrocki, S. Sierpowski, Poznań 2004.

${ }_{70}$ B. Ryszewski, Problemy komputeryzacji archiwów, Toruń 1994, s. 18-19; W. Kwiatkowska, Wptyw komputeryzacji archiwów na metodykę archiwalna, Archiwista 
Występujące w ostatnich latach coraz powszechniej w środowisku archiwalnym zjawisko lekceważenia dotychczasowego dorobku teoretyczno-metodycznego i odchodzenia od potrzeby naukowego opracowywania akt nie ma żadnego uzasadnienia w zmianach, które zaszły w technice pracy, ani w funkcjach archiwów ${ }^{71}$. Wydaje się, że nadal jako fundament prac archiwalnych należy traktować zasadę proweniencji i wynikający z niej porządek archiwalny: zespołów i całych zasobów. Warto w tym miejscu przypomnieć słowa Ryszarda Przelaskowskiego: „A że w życiu wszystko się rozwija i zmienia - stąd też dezaktualizacja kryteriów, które decydowały o układzie katalogów i skorowidzów, stąd ich starzenie się i konieczność bardziej nieruchomej podstawy, której one są nadbudową. Tą podstawą są właśnie prace rekonstrukcyjne, oparte na zasadzie proweniencji"72.

\section{Traditional model of archive holding analysis (arrangement and description) and its meaning in contemporary times}

Summary

The aim of this article is to recollect the most important principles and methods that establish the traditional model of the archival holding arrangement and description. This model was the achievement of inter-war archivists, and then was completed and concluded in the first post-war years.

In the light of the article, the basic principle that was to be respected while arrangement the acts was the principle of provenience. As its consequence, a new method of the reconstruction of archival fond appeared. The new method consisted of a number of research studies and technical procedures leading to the appointment of an archival fond to arrange and establish archival aids. The scope of arrangement works and the form of basic archival aid, that is inventory, together with hierarchical structure of other aids were established. In its general theoretical basis, outlined research method and the way of realization of particular levels of works, this procedure has been valid till today. The development of methodology that took place following years both broadened and modi-

Polski, nr 3, 2003, s. 34-37; taż, Budowa elektronicznego systemu informacji archiwalnej $w$ Polsce. Stan obecny i perspektywy, Archiwista Polski, nr 2, 2007, s. 81-91.

${ }^{71}$ Potwierdzeniem niekorzystnych zmian w metodyce opracowania są wprowadzone do stosowania w archiwach państwowych w roku 2003 Wskazówki metodyczne NDAP z dnia 10 grudnia 2002 roku dotyczace uproszczonego opracowania zasobu archiwalnego przechowywanego w archiwach państwowych [on-line]. [Dostęp lipiec 2008 r.]. Dostępny w World Wide Web: http://www.archiwa.gov.pl/?CIDA=152; W. Kwiatkowska, Miejsce opracowania zasobu.

72 R. Przelaskowski, dz. cyt., s. 32. 
fied some of the arrangements of Polish classic archivists. The evolution in the understanding of the provenience principle together with the related fond notion took place. The detailed methodology developed and it adjusted a general model to the specific nature of arrangement of defined types of fonds and records. Separate norms of inventory for particular types of records were established. 